Article

\title{
Renewable Energy as a Catalyst for Equity? Integrating Inuit Interests With Nunavik Energy Planning
}

\author{
Antoine Paquet ${ }^{1, *}$, Geneviève Cloutier ${ }^{1}$ and Myriam Blais ${ }^{2}$ \\ ${ }^{1}$ School of Planning and Regional Development, Laval University, Canada; E-Mails: antoine.paquet.3@ulaval.ca (A.P.), \\ genevieve.cloutier@esad.ulaval.ca (G.C.) \\ 2 School of Architecture, Laval University, Canada; E-Mail: myriam.blais@arc.ulaval.ca \\ * Corresponding author
}

Submitted: 30 April 2021 | Accepted: 20 August 2021 | Published: 16 December 2021

\begin{abstract}
Nunavik's residents experience significant social and environmental disruptions due to climate change. These disruptions add to the widespread changes that the Inuit have encountered over the last century-changes that have left this community totally dependent on fossil fuels for heat and power. Over time, Nunavik's residents have taken control of petroleum resources and their distribution, transforming this energy source into a major regional economic asset. Recently, there has been a transition towards renewable energy technologies (RETs) in Nunavik. However, are these alternative sources of energy appealing to local residents? This article explores the potential of RETs through the lens of procedural and substantive equity in the context of Inuit interests and integrated sustainability. Based on informal discussions with Inuit residents, interviews with stakeholders of the energy transition in Nunavik, and a literature analysis, this article presents two main results: (1) The level of substantive equity depends mainly on the type of RET and on idiosyncrasies between communities, and (2) local governance and procedural equity need to be asserted so that RETs can become true catalysts for equity.
\end{abstract}

\section{Keywords}

climate change; energy transition; equity; indigenous; Inuit; Nunavik; perceptions; planning; renewable energy; sustainable development

\section{Issue}

This article is part of the issue "Planning for the Local Impacts of Climate Change: Nobody Left Behind?" edited by Mark Seasons (University of Waterloo, Canada).

(C) 2021 by the authors; licensee Cogitatio (Lisbon, Portugal). This article is licensed under a Creative Commons Attribution 4.0 International License (CC BY).

\section{Introduction}

Located north of the 55th parallel in the province of Quebec, Canada (Figure 1), Nunavik is home to some 12,000 people, mostly Inuit (Duhaime et al., 2015). Like many other circumpolar territories, Nunavik is already experiencing climate change impacts (Larsen et al., 2014). These are on top of the impacts that were caused by a sudden modernization period in the 1900 s, during which northern villages developed a strong dependence on fossil fuels for heating and electricity production. These imported methods shaped the physical organization of the villages and impacted traditional aspects of the Inuit lifestyle (Duhaime, 1985). However, they also presented incredible economic potential: Today, petroleum distribution represents a growing business that is completely Inuit-owned, creating jobs and investment across the Nunavik region.

Northern villages remain fossil-fuel dependent (Rodon \& Schott, 2014), but new projects are now aimed at using renewable energy technologies (RETs). However, RETs do not necessarily assure equity. The roles of the Inuit and the qallunaat (non-Inuit people) in the planning process-from defining people's needs to the services supplied by the built infrastructure-are often minimized, as shown by the dominant role of the federal and provincial governments over the last several decades (Breton \& Cloutier, 2017; Chabot, 1995). In our study, 
we consider the equity of both the planning process and the outcomes in the assessment of how planning for RET projects may benefit the communities and integrate Inuit perspectives. We aim to explore how the Inuit could benefit from RETs and evaluate how planning and decision-making processes incorporate local impacts and outcomes. More broadly, we examine the way these processes consider the Inuit communities' interest in these technologies. Based on informal discussions with Nunavimmiut (Nunavik's residents) in Kangiqsualujjuaq, interviews with key respondents and on-site observations, our findings show that if the current state of diesel dependence and the associated environmental harms are well understood, Nunavimmiut seem to prefer some RETs more than others. These preferences however vary between villages, which reinforces the importance of gaining insight into local interests and perspectives in the early stages of energy production projects.

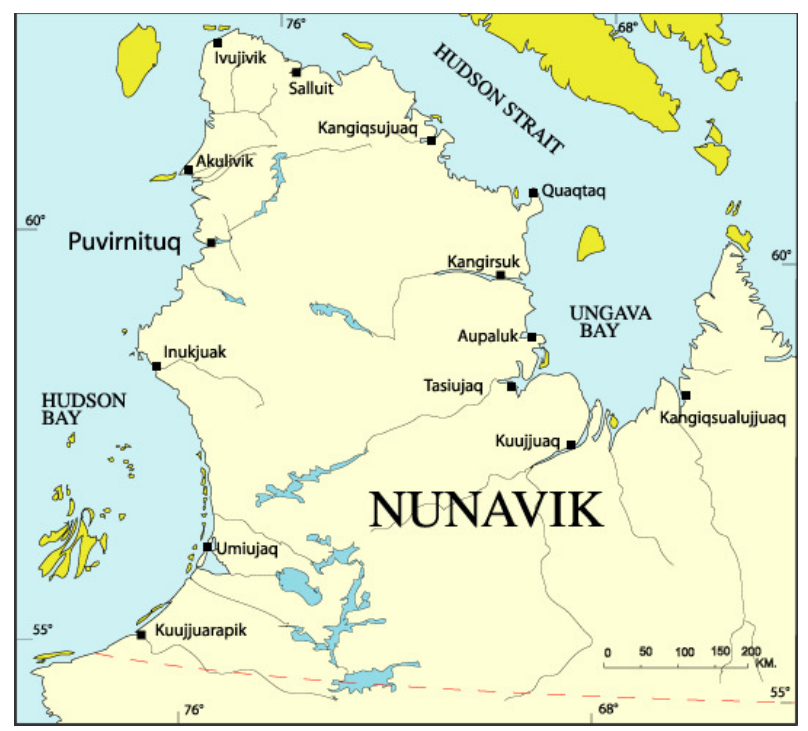

Figure 1. Nunavik and its 14 Inuit communities. Source: Makivik Corporation (n.d.).

\section{Climate Change and Energy Production in Nunavik}

\subsection{Climatic Precariousness and Inuit Culture}

Northern Canada, including Nunavik, is undergoing rapid and major "climate-driven environmental, societal, and economic changes" (Larsen et al., 2014, p. 1572), such as high rates of warming. Nunavik is geographically isolated. It is only accessible by plane and twice a year, it receives shipments by boat. This isolation, in addition to other issues such as an escalating housing crisis, food insecurity and dependence on fossil fuels, make the Nunavimmiut highly vulnerable to climate change (Allard et al., 2012; Duhaime et al., 2015; Rodon \& Schott, 2014).

The impacts of climate change are already apparent in Nunavik's communities (Cuerrier et al., 2015; Downing \& Cuerrier, 2011; Rapinski et al., 2017). These impacts are not just a warning-bell for the environment, but they are also an alarm for threats to physical and psychological health, the subsistence economy, local spirituality, and the Inuit way of life (Durkalec et al., 2015; Ford et al., 2012). For example, the shorter ice season and reduced ice thickness that result from climate change are not only environmental concerns, but they also put Inuit hunters and ice-fishers at risk (Durkalec et al., 2015; Ford et al., 2018; Watt-Cloutier, 2019). Economic insecurity is caused by the limited access to once accessible icy territories (Ford et al., 2012), as well as a loss of the functional, spiritual, and aesthetic qualities of ice that is anchored in the Inuit culture (Heyes, 2011). Infrastructure is affected by the freezethaw events that affect the permafrost and disrupt the soil surface (Allard et al., 2012). The potential effects of climate change on Nunavik's fauna and flora, the very core of Inuit food sources and subsistence economy, are also alarming (Kendrick, 2013; Newell et al., 2020; Watt-Cloutier, 2019).

As some of our interviewees confirmed, the global scale of climate change is well understood by the Inuit. Despite Nunavik's low contribution to provincial greenhouse gas (GHG) emissions, "global warming is inherently a cumulative environmental problem" (Weis, 2014, p. 6), and the use of more RETs remains necessary. However, the transition to more environment-friendly alternatives must be applied as a means of sustainable development and implemented through local Inuit governance and must not impose non-Inuit solutions on these northern communities.

Some climate adaptation measures have already been implemented in circumpolar regions. These efforts occur mainly "reactively in response to observed change in climatic conditions" and "were initiated at the individual/household level" (Ford et al., 2014, p. 4) in more than half of the cases. However, only a handful of RET projects and prototypes have been carried out to completion in Nunavik. As discussed, such projects must not only represent an environmental gain to be truly sustainable (Klinsky et al., 2017). They must also be respectful of the Inuit culture and traditional activities, encourage local governance and empowerment, and stimulate local economic growth and diversification (Rodon, 2017). In order to have a better grasp of where energy production in Nunavik is headed, we must first understand where it comes from.

\subsection{Fossil Fuel Dependence and Appropriation}

Before qallunaat settled in Nunavik in the beginning of the 20th century, heating systems in the Arctic were versatile and were adapted for limited access to wood (Odgaard, 2003). This gave the Inuit the flexibility they needed during their periodic journeys as a seminomadic people (Hervé, 2019). After newcomers from areas located further to the south of the province (hereafter referred to as "the south") built their trading posts 
and settlements, the Inuit went through a fast sedentism process. The Hudson's Bay Company (HBC) encouraged the Inuit to use their knowledge of the land to trap arctic foxes and trade their fur for commodities, drawing some families closer to the qallunaat installments (Duhaime, 1985). In the early 1930s, the fur-trade market crumbled and there were frequent epidemics and famine. The presence of basic medical care and a steady food supply in the proto-villages led Inuit families to permanently settle nearby and build rudimentary houses with materials that could be found on-site (Chabot, 1995). However, since the HBC did not sell construction materials, "the Inuit rarely had the financial means to build and if they did, they still couldn't afford to heat their homes" (Christensen, 1953, as cited in Duhaime, 1985, p. 20). The poor housing situation prompted the involvement of the federal and provincial governments in social housing programs in Nunavik (Breton \& Cloutier, 2017), which now represents $96 \%$ of the region's real estate (Therrien \& Duhaime, 2017).

During that time, the area experienced a shift in energy sources. The once versatile and impermanent hearths and oil lamps of the Inuit semi-nomadic lifestyle were replaced by heavy stoves. Heat, once transportable and temporary, became fixed and constant (Figure 2). As explained by Duhaime (1985, p. 37), "the Inuit excitedly looked to the homes of whites, because they were warm."

Soon after, these heating systems and newly installed communal powerplants were all producing energy through fossil fuel combustion (fuel oil for heating, diesel for electricity). They depended on government subsidies to operate at a reasonable cost, as mentioned by some interviewees. Nunavimmiut still remain $100 \%$ depen- dent on fossil-fuel-generated energy (Rodon \& Schott, 2014), which requires yearly petroleum shipments and the regional management of this resource (Figure 3). In the 1960s, petroleum was managed by the Quebec government, the $\mathrm{HBC}$, and the Shell fuel company. However, 20 years later, the Inuit began to manage the petroleum themselves. The Fédération des Coopératives du Nouveau Québec (FCNQ), an Inuit-owned entity, gained control following an agreement with the three stakeholders and started buying most of the villages' oil tanks (FCNQ, 2018). From that point on, diesel and fuel oil supplies have been operated by and for the Inuit people, bringing in capital for all their communities.

\subsection{Towards a Renewable Transition}

Some RET projects are starting to appear in Nunavik. A run-of-river hydroelectric powerplant is being built in Inukjuak, solar panels have been installed in Quaqtaq, an operational biomass-heated sports center has been built in the Cree community of Whapmagoostui and two wind turbines are in use at Raglan mine between Salluit and Kangiqsujuaq. Other projects have been considered, such as connecting the northern villages of Nunavik to power grids south of its borders, installing underwater turbines in Kuujjuaq and introducing the use of tidal power, but these have been put on hold (Kativik Regional Government \& Makivik Corporation, 2012). Regardless of the well-documented environmental benefits of these technologies (Owusu \& Asumadu-Sarkodie, 2016), the way in which Inuit communities would benefit from the planning of these RETs is not yet understood. Are such planning interventions equitable, both in terms of the process and the outcomes?

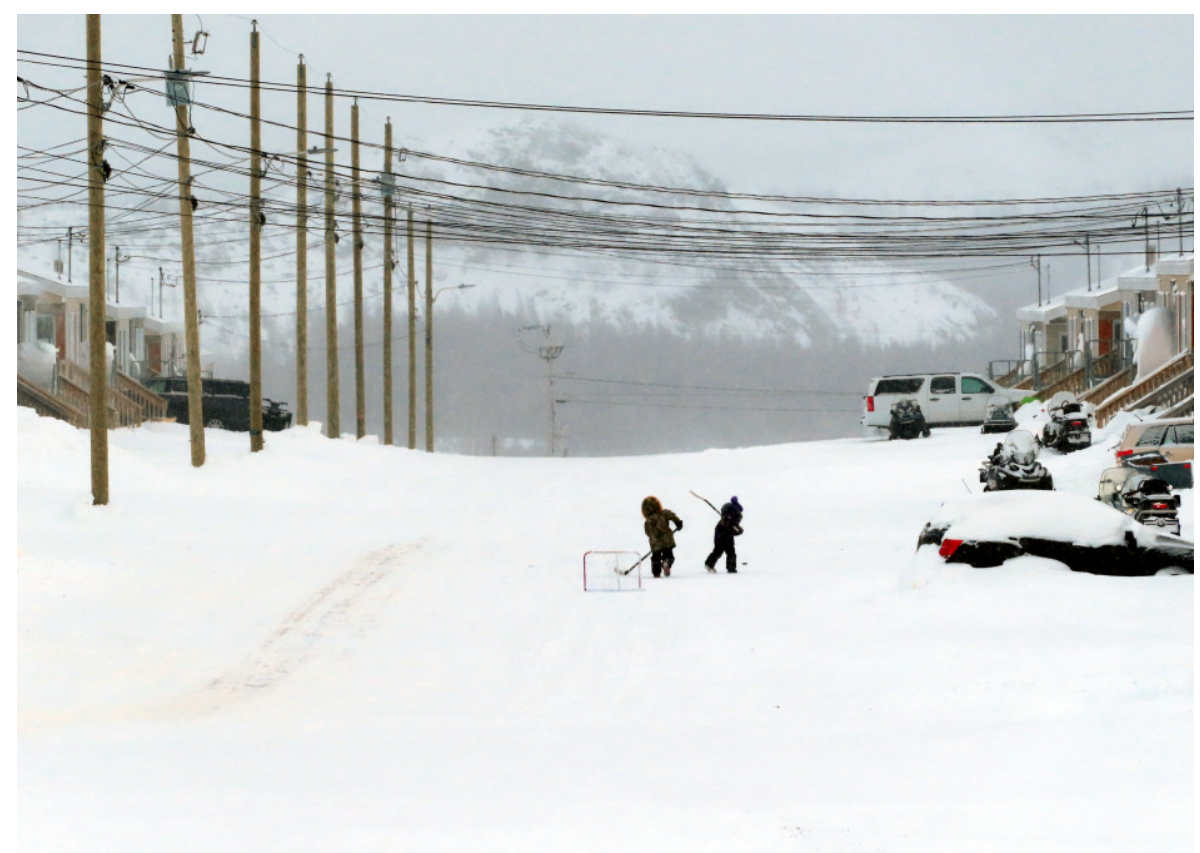

Figure 2. Young Kangiqsualujjuamiut playing under powerlines, a sign of a now sedentary lifestyle. 


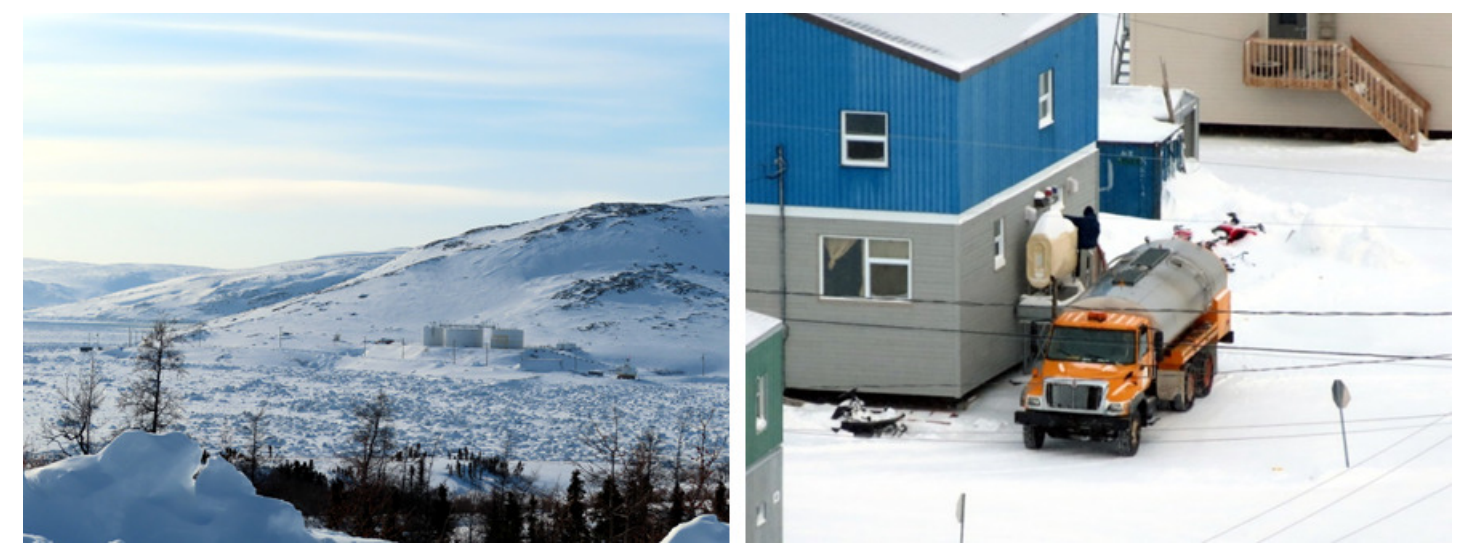

Figure 3. Local management of fossil fuels: Community tanks in Kangiqsualujjuaq (left) and a Kangiqsualujjuamiut employee filling a residential tank with fuel oil (right).

\section{Addressing Equity in Planning}

\subsection{What Makes Planning Equitable?}

Since local and regional governments are now required to plan for sustainability, in addition to the economy and environment, equity has become a fundamental part of planning (Campbell, 1996). In climate action planning, social and racial equity is often evaluated based on the number of green initiatives and jobs created, or through the investments in low-income neighborhoods and communities (Agyeman, 2005; Schrock et al., 2015). In this way, planning for sustainability often focuses on concrete outcomes and tends to overlook aspects related to the dynamic nature of the planning process, such as selfaffirmation, capacity, and learning (Young, 1990).

However, focusing solely on the planning process does not fully address the stakes in terms of power dynamics, especially in contexts that are marked by domination, such as that of the indigenous population. Even when the planning process aims at inclusive social representation, it can lead to inequitable outcomes (Chu et al., 2017; Fainstein, 2005). In participatory processes, experts and elites tend to receive the most attention; this also applies to climate action plans (Meerow \& Woodruff, 2020).

To achieve equitable planning, both the planning process (procedural equity) and the outcomes (substantive equity) must be integrated (Innes \& Booher, 2015). Participatory and community-based approaches to climate action planning are essential to ensure that planning practices are based on local needs, values, capacities, and priorities (Cloutier et al., 2015). Such approaches lead to developing a shared understanding of issues and outcomes and result in a greater capacity for climate change action over time (Archer et al., 2014; Finn \& McCormick, 2011).

An equitable approach to planning also benefits from intersectional and decolonized perspectives (Kovach, 2009; Porter et al., 2020). This type of post-structuralist perspective considers how environmental risk and eco- nomic inequality interact with gender identity and race. When examined on a micro-scale, as in our study, this addresses the specific context that characterizes these northern indigenous communities. To ensure equitable planning, it is essential to acknowledge the specific intentions of Inuit, and the new methods they are developing for living in and planning the territory (Desbiens, 2017).

Sustainable development is generally represented as the area in which three independent spheresenvironmental, social, and economic-overlap (Figure 4). However, this representation is mainly sectorial: it implies that all the individual spheres can exist on their own. Adapting this concept to an integrated form that is more coherent with an indigenous perspective (Matunga, 2013) can be a step towards integrated procedural equity.

\subsection{Rethinking Sustainable Development}

Henderson (2000, p. 268), a member of the Chickasaw Nation, states that indigenous people "share an ecological vision of society that is enfolded in a view of interactive harmony" and that "if we are to live in harmony, we must accept the beauty and limits of our ecology." The indigenous worldview considers all forms of life as being connected, which is reflected in the concept of relationality (Matunga, 2013). The notions of interaction, harmony, and relationality therefore appear to be key in the way indigenous people perceive the world. These concepts should be adapted into the western sustainable development model.

With this in mind, in our study, we interpret sustainable development differently from its general conception. Adapted from the model of Cosmic Interdependence by Mebratu (1998), our interpretation (Figure 4) integrates relationality as projects, and choices are defined by the relationship between three nested cosmoses: land, social, and economic. The intersection between the three cosmoses "is the area where we have millions of combinations of conflict and harmony serving as a seedbed for the process of coevolution of the 

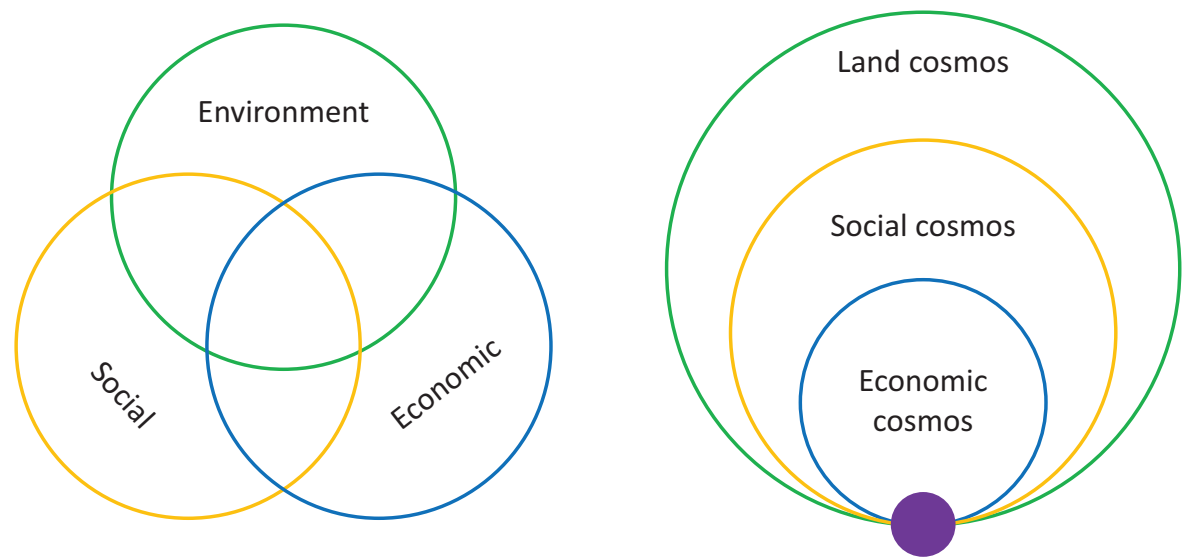

Figure 4. From a sectoral model of sustainable development (left) to an integrated one (right). Source: Authors' work, adapted from Mebratu (1998).

natural and human universe" (Mebratu, 1998, p. 514). In planning, these possible interactions shape projects and can be represented by a governance system.

\section{Methodology}

This research is part of a broader, multidisciplinary research project that aims to evaluate alternatives to diesel and fuel oil for electricity production and heating in Nunavik in the context of the ongoing energy transition. This venture was mainly centered on applied methods in the fields of engineering, economics, and architecture. The research presented in this article applies a social lens to what are typically technical perspectives in order to better understand Inuit interests and perceptions on matters concerning the energy transition.

This program is also part of a partnership between Inuit and Innu organizations and public organizations and researchers (Sentinel North-Doing Things Differently) based out of areas south of Nunavik. Through the years, researchers have developed collaborative relationships with many indigenous communities in the province of Quebec, including the northern village of Kangiqsualujjuaq (see Trottier et al., 2020; Vachon et al., 2019). In February 2020, a team of people established through this partnership stayed in Kangiqsualujjuaq and collected on-site data.

The project was subject to a full examination by the Ethics Committee at Universite Laval. The aims of our research and our methods were officially approved by the organization, providing us with the opportunity to move forward (approval number 2020-034). All residents and respondents verbally consented to taking part in this research prior to participating.

The study was conducted based on the triangulation of data obtained through multiple qualitative methods. First, we participated in informal discussions with Inuit residents of Kangiqsualujjuaq (hereafter referred to as "residents," see Table 1). We conducted on-site observations of daily life in the village and took notes on the func- tioning of the energy system. Our multidisciplinary team of researchers specializing in urban design and architecture stayed in the village for one week in late February 2020. Discussions with residents mainly took place at the local Coop Store (Figure 5) and addressed issues listed in Table 1. Notes were taken during the discussions, but conversations were not recorded. Additional visits to Kangiqsualujjuaq and other northern villages were initially planned but had to be cancelled due to the Covid-19 pandemic. Unfortunately, further discussions with Nunavimmiut were not possible due to the sanitary restrictions and a lack of a reliable internet connection in many Nunavik households. Second, we focused on the actual decision-making process and on the perspectives of stakeholders on the transition to RETs that had already begun in Nunavik. Semi-structured interviews were conducted virtually with energy transition stakeholders (hereafter referred to as "respondents," see Table 1), who mostly work and live in the southern part of Quebec. These interviews were recorded, transcribed verbatim, and coded using two content analysis methods: a multi-category approach that groups respondent answers according to theme and resemblance and an analysis focused on the opinions of the interviewees on certain subjects. Six principal categories were used during the analysis: (1) procedural equity, (2) substantive equity, (3) local knowledge and resources, (4) external resources and relation with the community, (5) perceptions and interest in energy and its role in Nunavik development, and (6) technical elements and scale of intervention. Third, a content analysis was conducted for the current energy programs, planned energy projects, Inuit consultation reports and literature, and peer-reviewed articles. The triangulation of these three methods provided perspective on cultural discourse about the energy transition (content analysis and interviews), Inuit habits (observations), Inuit worldviews and perceptions (informal discussions with Inuit residents), and characteristics of the planning process (content analysis and interviews). This, in turn, provided an understanding of how 
Table 1. Participant profiles and addressed issues.

\begin{tabular}{|c|c|c|}
\hline & Participant profiles & Addressed issues \\
\hline $\begin{array}{l}\text { Informal discussions in } \\
\text { Kangiqsualujjuaq } \\
\text { (residents) }\end{array}$ & $\begin{array}{l}\text { Brief discussions with } 38 \text { Inuit residents: } \\
\text { - } 20 \text { men and } 18 \text { women; } \\
\text { - Eight youth, } 21 \text { adults, nine elders. }\end{array}$ & $\begin{array}{l}\text { - Areas of interest in and around the } \\
\text { village and what makes them special } \\
\text { (social space, traditional activities...); } \\
\text { - Housing issues; } \\
\text { - Aspects of daily life (electricity, heat, } \\
\text { internet...); } \\
\text { - Knowledge of RETs. }\end{array}$ \\
\hline $\begin{array}{l}\text { Semi-structured interviews } \\
\text { (respondents) }\end{array}$ & $\begin{array}{l}\text { 60-minute interviews with nine of the } \\
\text { Nunavik energy transition stakeholders } \\
\text { (codes R1 to R9): } \\
\text { - Seven men and two women; } \\
\text { - Eight qallunaat and one Inuit; } \\
\text { - Three researchers, three organisations } \\
\text { based in the south, and three based in } \\
\text { the north. }\end{array}$ & $\begin{array}{l}\text { - Personal experiences related to energy } \\
\text { in Nunavik; } \\
\text { - Organisational engagement in the } \\
\text { transition; } \\
\text { - Existing and upcoming RET projects; } \\
\text { - Governance approaches. }\end{array}$ \\
\hline
\end{tabular}

sustainable development cosmoses interact with RET projects in Nunavik and the ability to assess their level of integration. This project can therefore be categorized into the interpretative paradigm of qualitative research (Yin, 2011).

We analyzed RET projects based on procedural equity (the integration of Inuit interests in the decision making

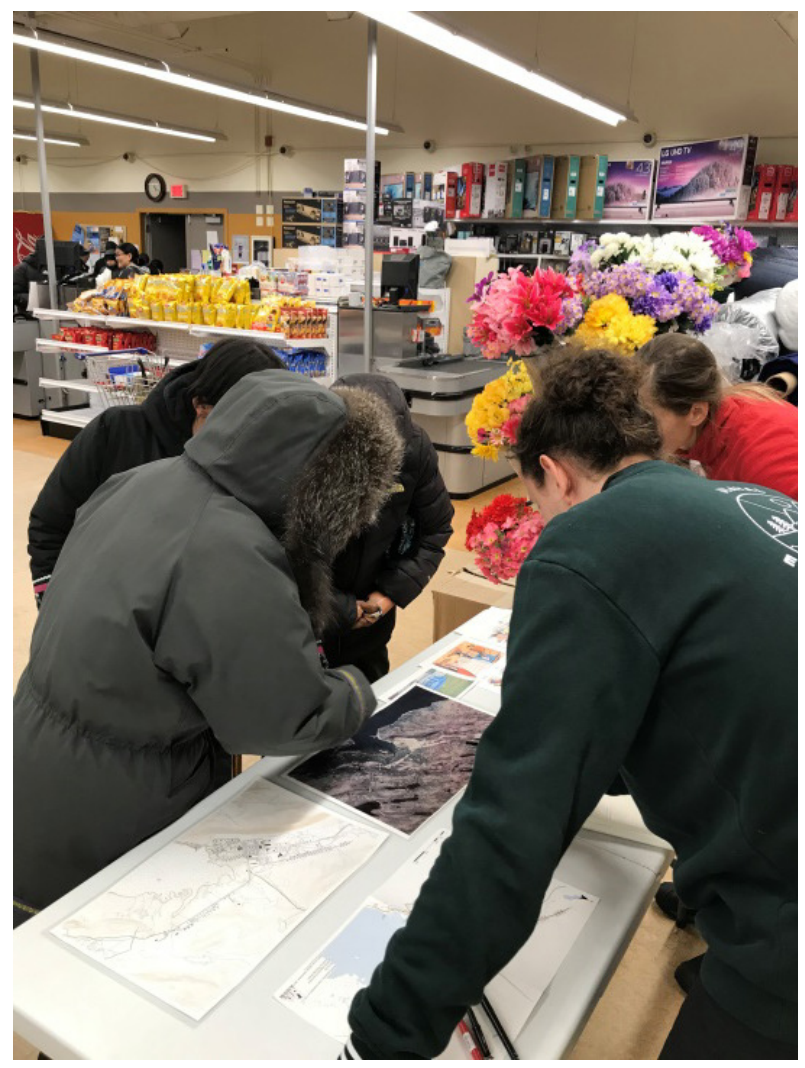

Figure 5. Informal discussions with Inuit residents at the Coop Store in Kangiqsualujjuaq, February 2020. Source: Trottier et al. (2020). and planning processes) and substantive equity (the impacts and benefits for the Inuit). This assessment allows us to highlight the potential inequitable impacts that energy projects may have for Inuit communities and the key elements that shape RET projects into catalysts for equity.

\section{Results and Discussion: Equity, Outcomes, Processes, and Inuit Interests}

As stated, equity in planning corresponds with an evolving planning process and the resulting outcomes. Both are important to determine whether the transition towards RETs is equitable and in the best interest of the Nunavimmiut. However, the characteristics that are unique to each Inuit community must first be considered to ensure the integrity of our analysis.

"It depends on the community." This statement from an interviewee summarizes a concern about energy planning in Nunavik that is shared by all respondents. Though many Inuit share a common epistemology and way of thinking based on relationality, as do other indigenous nations (Wilson, 2008), perspectives may differ from one village to another. Some communities have strong rivers, while others have strong winds. Some may be reluctant about RETs, while others may embrace them. The diesel powerplant might be located right by the school or far up a hill depending on the village and its surroundings. The list goes on. This highlights one of our initial observations: There is no universal solution. The impacts as well as the feasibility and acceptability of a project will differ from place to place (see Makivik Corporation et al., 2014; McDonald \& Pierce, 2013), meaning that planning must be done at the community level to address the specific hopes and needs of that community. Such singularities are considered in the following analysis, both by looking at the current energy situation and by exploring renewable alternatives. 


\subsection{Renewable Energy and Substantive Equity}

\subsubsection{The Energy Situation Today}

Respondents were unanimous when asked about the state of fossil fuel dependence in Nunavik: it is now strongly rooted in the communities' practices. One respondent agreed that "diesel is here to stay" (R4) because it's a known and reliable energy source. This respondent was supported by another, R3, who somewhat pessimistically said that "you'll always have the need for diesel." As previously mentioned, the lucrative local management of fossil fuel resources was seen as a benefit, although from the southern perspective, R1 and R7 said that operating northern thermal powerplants is an economic "black hole." Regardless, all nine respondents were in favor of transitioning towards renewable energy sources, mainly because of the environmental impacts of diesel-produced electricity, such as GHG emissions, air pollution and soil contamination ("everybody knows that," as one Inuit said).

One Inuit resident of Kangiqsualujjuaq stated unambiguously that "the village needs something other than dirty energy." These words were based on environmental concerns but were also about energy security. Currently, houses in Nunavik are heated by electrically operated fuel oil furnaces. This raises two points of concern: (1) Heating requires a double intake of fossil fuels, with diesel-generated electricity powering fuel-oil furnaces, and (2) when there is a power outage, the heating system shuts down. As R3 indicated, "you run out of fuel, your house can freeze within 24 hours or so, the plumbing bursts, you have big water damage all over the house... that's bad news." An elderly resident stated that "without electricity, we suffer." An alternative to diesel generators, even just as a back-up energy source, would therefore be greatly appreciated.

The impacts of diesel and fuel oil are diverse. One Inuit resident pointed out that even when the olfactive impact is small, there is still an auditive impact, saying, "when it's quiet, it's like a giant mosquito is coming." Three respondents also indicated that in villages where the power stations are in the town center, odors and sounds can become a "nuisance" (R4) to nearby residents. R8 experienced a significant difference after a powerplant was relocated farther away from the village. The risks associated with petroleum leaks in the environment (see McDonald \& Pierce, 2013; Mercer et al., 2020; Weis, 2014) were also mentioned multiple times.

\subsubsection{Possible Alternatives}

Table 2 presents a triangulation of data collected during informal discussions, on-site observations, interviews, and from literature reviews on the interest of Inuit in various RETs. As mentioned, this triangulation included data that were obtained from multiple methods and then integrated to detect contradictions or repetitions concern- ing the interest of the Inuit or those living to the south regarding RETs. On most occasions, answers overlapped, reinforcing the respondents' degree of approval or disapproval of the RETs' outcomes. All data were interpreted from the perspective of Inuit interests: statements from Inuit sources were given more weight than statements from the literature. For example, a non-Inuit source indicated that the Inuit found wind power to be respectful of their traditional activities, while an Inuit source implied that there were important nuances to consider regarding the complaints about this technology. The outcome is therefore recorded as moderately negative instead of positive or neutral.

These interests are divided into the three cosmoses of sustainable development and the governance system that regulates their interactions, as presented in Figure 4. This representation allows for a general overview of the interest of Inuit and non-Inuit in RETs.

Two levels of information are presented in Table 2. First, the table compares alternative RETs in terms of Inuit interests. Second, it compares the attitudes and perspectives that Inuit and southerners (composed of qallunaat and organizations based in the south) have on RETs, allowing us to examine some cultural differences in perception.

According to our results, solar panels are the most appreciated alternative energy source. Despite the economic and governance interests being less certain among Inuit, the land and social cosmoses are positively perceived. However, one respondent specified that building-mounted solar panels are preferable to solar farms, which monopolize land for only one purpose and require more roads and gravel pad foundations to be built. Another respondent referred to a case in Quaqtaq where both types of solar installations exist and stated that the residents seem to appreciate when the equipment is less visible.

The qallunaat consider wind power to be a great solution for Nunavik, but the Inuit see this energy source as creating more uncertainty. The Inuit understand that wind turbines emit less GHG emissions but find other issues worrying. Notably, the potential impacts on birds and their migration patterns were mentioned during interviews and are documented in the literature (Makivik Corporation et al., 2014; McDonald \& Pierce, 2013). Hydroelectricity powerplants and hydrokinetic power elicited concerns about the migration patterns of different fish species. However, run-of-river hydroelectricity was viewed more positively, mainly because it did not require flooding land and ecosystems that can be used for traditional activities (Makivik Corporation et al., 2014).

There are strong feelings of inequity surrounding the current off-grid situation in Nunavik. Some respondents confirmed that connecting their region to Quebec's main power grid is an onerous project that would leave few-to-no local governance or economic benefits in Inuit communities. Others see this as lacking fairness and 
Table 2. Inuit and southerners (composed of qallunaat and organizations based in the south) interest in diesel and RET projects in Nunavik. Outcomes are color-coded. Green: positive or neutral outcomes, yellow: moderately negative outcomes, red: strong negative outcomes, grey: a lack of information. Other alternatives include biomass, hydrokinetic and geothermic energy.

\begin{tabular}{|c|c|c|c|c|c|c|c|c|}
\hline & & Diesel & $\begin{array}{l}\text { Wind } \\
\text { power }\end{array}$ & $\begin{array}{l}\text { Solar } \\
\text { panels }\end{array}$ & $\begin{array}{l}\text { Hydroelectricity } \\
\text { (dams) }\end{array}$ & $\begin{array}{l}\text { Hydroelectricity } \\
\text { (run-of-river) }\end{array}$ & $\begin{array}{l}\text { Connexion } \\
\text { to Quebec's } \\
\text { grid }\end{array}$ & $\begin{array}{c}\text { Other } \\
\text { alternatives }\end{array}$ \\
\hline \multirow{2}{*}{$\begin{array}{l}\text { Land cosmos } \\
\text { Respect for the } \\
\text { land and the } \\
\text { environment and } \\
\text { fight against climate } \\
\text { change/adaptation } \\
\text { to its impacts }\end{array}$} & Inuit & & & & & & & \\
\hline & Southerners & & & & & & & \\
\hline \multirow{2}{*}{$\begin{array}{l}\text { Social cosmos } \\
\text { Respect for } \\
\text { traditional activities, } \\
\text { quality of life and } \\
\text { harmonization of } \\
\text { spatial use }\end{array}$} & Inuit & & & & & & & \\
\hline & Southerners & & & & & & & \\
\hline \multirow{2}{*}{$\begin{array}{l}\text { Economic cosmos } \\
\text { Local economic } \\
\text { benefits and } \\
\text { economic viability }\end{array}$} & Inuit & & & & & & & \\
\hline & Southerners & & & & & & & \\
\hline $\begin{array}{l}\text { Governance } \\
\text { Decision power in }\end{array}$ & Inuit & & & & & & & \\
\hline management & Southerners & & & & & & & \\
\hline
\end{tabular}

equity. Inuit participants in the 2013 Parnasimautik panNunavik consultation stated that "the electricity produced in Nunavik should benefit Nunavik Inuit first," and that they "live close to the hydroelectric dams but the power is sent to Americans" (Makivik Corporation et al., 2014, Appendix 4). Although a feasibility study was completed by a private firm in 2003 (Kativik Regional Government \& Makivik Corporation, 2012), R4 indicated that the project has been abandoned for now.

Other alternatives, such as biomass, hydrokinetic and geothermic energy, were only sporadically mentioned in discussions and interviews. Only a few residents of Kangiqsualujjuaq seemed aware of those alternatives, specifically of the use of tidal energy. However, answers on that topic were too fragmented and the technology itself was not understood well enough to be able to demonstrate a convincing degree of interest in its implementation.

Inuit and qallunaat interests were similar in the land and social cosmoses but mostly differed in the economic and governance spheres. The differing economic perspectives can be explained by the potential loss of Inuit jobs in the diesel distribution sector as well as by the lack of local scientific and technical skills to understand and properly maintain RETs. This also impacts local governance by reducing the role of Inuit-managed petroleum supply and potentially creating a new dependence on the south for specialized knowledge. R5 stated that when issues with solar panels arose, it took about three weeks for specialized maintenance staff from Ottawa to arrive.

\subsection{Procedural Equity Over Time}

In Table 2, procedural equity is mainly represented through the governance system. However, this depiction only shows achievable governance outcomes in possible futures. Figure 6 depicts the evolution of this governance over the last 50 years or so. Data were treated in a similar way as they were in Table 2, but with an added temporal dimension.

Three main observations can be made from this sustainability timeline. First, there is a marked improvement in environmental and social outcomes over time. According to R4, this improvement can be attributed to cleaner diesel energy production methods. It might also be due to the rising concern among project developers for social acceptability in planning, especially in indigenous contexts (Barry \& McNeil-Cassidy, 2019). Second, economic outcomes also increased with the creation of jobs following the local control of petroleum distribution. Third, regardless, local governance followed a different trend. It went from being nearly nonexistent to having great importance in the diesel era. However, with 

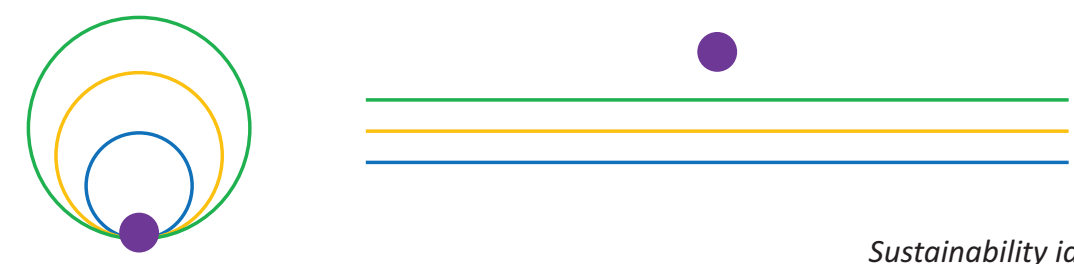

Sustainability ideal
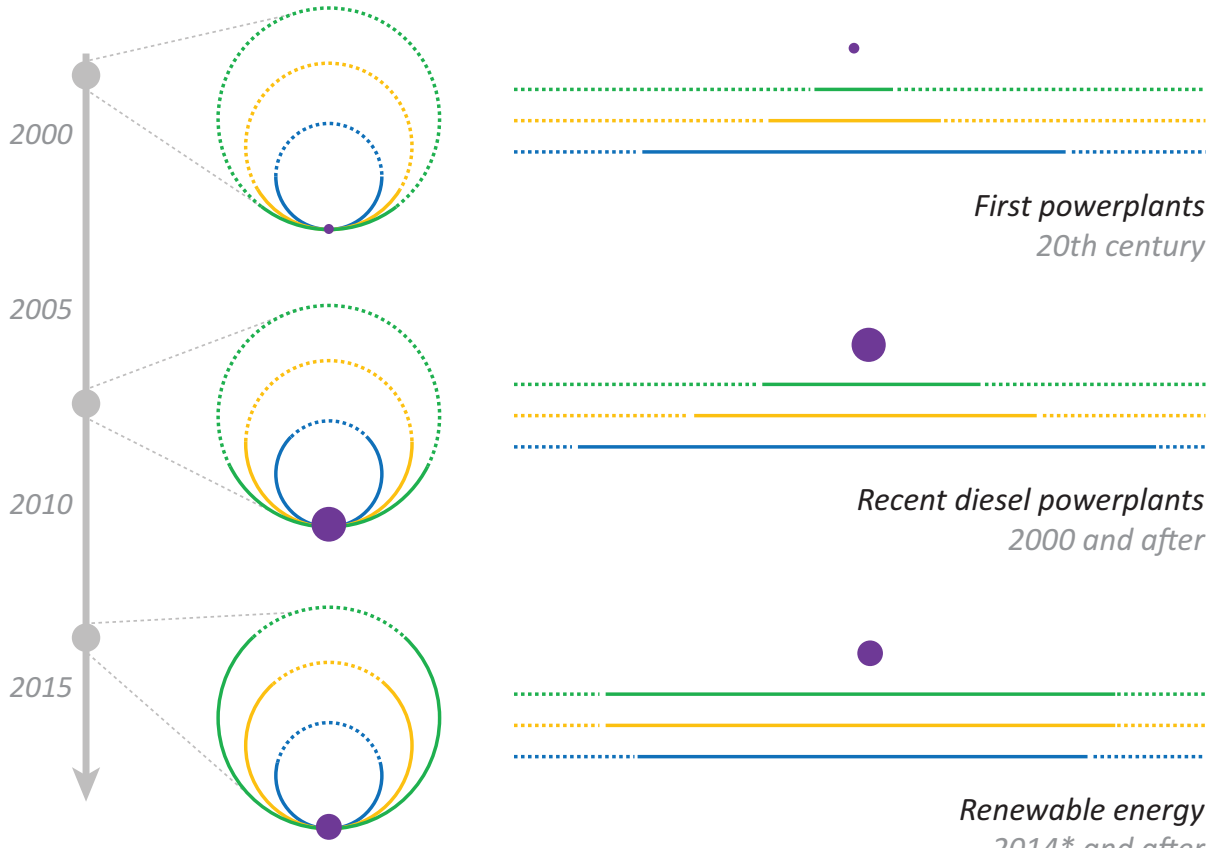

First powerplants 20th century

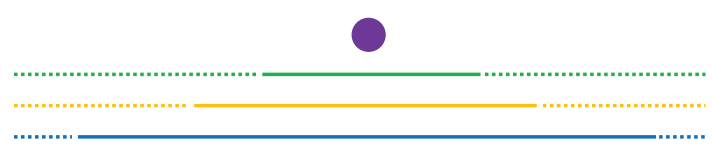

Recent diesel powerplants 2000 and after

Renewable energy 2014* and after

* First wind turbine installed at Raglan mine

Figure 6. Evolution of durability and procedural equity for energy production projects in Nunavik. The top depiction shows an ideal scenario with total sustainability and equity. The following depictions show the categories of sustainability through time as they relate to different technologies and sources of energy.

the arrival of complex RETs, local governance may take a step backwards.

Most respondents mentioned the importance of local will in order to have equity in RET planning. The example of Inukjuak's run-of-river hydroelectric powerplant, the result of a community-led idea, was often used to support that statement.

Four respondents also indicated the crucial role of providing proper training so that Nunavimmiut can perform maintenance on these new amenities. R3 said that "preventative maintenance should be done, but most of the time we're doing corrective maintenance, more like emergency repairs." The importance of government (both federal and provincial) subsidies for RET projects in Nunavik's remote villages was also emphasized by respondents. This financial support is needed to ensure the completion of projects and their resulting favorable impacts on the community. Respondents also stressed the importance of understanding and adapting to Inuit temporality and work methods for large-scale planning projects.

\subsection{What's Next?}

Some stakeholders of the energy transition in Nunavik foresaw this potential gap in local governance. In 2017, a joint venture between Makivik Corporation and the FCNQ called Tarquti Energy Corporation (hereafter Tarquti) was established. This entirely Inuit-owned enterprise specializes in RET project development in Nunavik. By becoming a major player in the energy transition, they hope to create jobs, local expertise, and economic benefits for all Nunavik communities (Makivik Corporation, 2019).

Such an initiative could strengthen local governance and the local economy in a clean-energy era. Being Inuit-controlled, Tarquti could compensate for losses in the diesel sector. However, because it is fairly new, Tarquti was not part of any of the RET projects we have mentioned. Nevertheless, Tarquti represents a step towards regional empowerment and local governance for Inuit. This corporation should therefore be involved in 
upcoming projects and become a cornerstone for equity in Quebec's northern RET sector.

Inuit entities such as Tarquti could bring local collaboration and indigenous perspectives into energy planning. Through Tarquti's focus on public consultation, RET projects would not only be developed by an Inuit enterprise, but they would work together with Inuit communities to better serve Inuit people.

\section{Conclusion}

This study aimed to evaluate how equitable RET project planning is for Inuit communities. By assessing current and potential energy projects in Nunavik through the lens of procedural and substantive equity, we addressed the unique position of these northern communities and acknowledged the intentions and aspirations of the Inuit residents with respect to their relationship with the land.

In terms of substantive equity, our results suggest that solar panels are a well-appreciated alternative to fossil fuel, especially when planned as building-mounted infrastructure. Hydroelectric dams were associated with the destruction of the land, while run-of-river infrastructure and wind turbines were the subject of concern for wildlife, an essential component of the Inuit subsistence economy. However, overall, these latter two alternatives were deemed feasible and of interest.

In terms of procedural equity, shifting the control of petroleum distribution to the FCNQ and the creation of local jobs in the energy sector helped increase the roles and responsibilities of Inuit organisations in the governance of energy production. However, because this empowerment is reliant on fossil fuels, it is put at risk without a careful transition to RETs. Past energy projects have often resulted in an inequitable distribution of power in the eyes of many residents. To avoid repeating past mistakes, future energy projects should be planned directly with the communities, operated by Inuit organisations, and centered around the three interrelated cosmoses of sustainable development.

Procedural and substantive equity are fundamental aspects that should be considered in every stage of planning; the promise of equity cannot be limited to energy transition projects alone. There should be equity in all aspects of planning throughout the social ecosystem, from housing and land use to public health. As indigenous ontology has suggested for centuries, "each ecosystem encapsulates and enfolds many forces or parts, none of which can enfold or encapsulate the whole" (Henderson, 2000, p. 260). Efforts to incorporate this philosophy into RET projects could be an important step towards sustainable, equitable and well-governed planning that respects the indigenous worldview.

So, are RETs a catalyst for equity in Nunavik? As shown, under the right circumstances, they can be.

New Inuit organizations aim to put Nunavimmiut, their worldview, and their interests at the center of the transition to RETs. With a process that focuses on
Nunavimmiut, aspects of the environment and the Inuit lifestyle that are linked to climate change, land protection, game hunting, fishing, and collecting berries could be better incorporated into planning. Implementing a planning process that is accepted by the Nunavimmiut would thus lead to a reduction in diesel dependence. Moreover, traditional activities and knowledge could even become pillars around which projects are conceived, developed, and implemented-an aspiration for many Inuit (Blais \& Pinard, in press; Vachon et al., 2017).

The Covid-19 pandemic led to significant constraints for this project. The most significant limitation was the restricted amount of time that the research team was able to spend in northern villages. More time would have allowed the team to gain more insight into Inuit perspectives on RETs and the energy transition. However, the methodology we used still allowed for our analysis to focus on the views of the Inuit in Kangiqsualujjuaq and non-Inuit in southern public organizations. In the future, validation of our data by the Kangiqsualujjuamiut and other Nunavimmiut would be beneficial. Such validation could help us to identify region-specific patterns in our results, as well as provide information about the evolution of these perspectives over time. The data we have already gathered provides a snapshot of the current perceptions of the energy transition and its production alternatives, which could then be compared with future data. For example, after the first projects by Tarquti Energy have been implemented, our data could be used to demonstrate how perceptions may have changed. More research on this subject would allow for a better understanding of the impact of these new innovative endeavours on Nunavimmiut.

\section{Acknowledgments}

We are deeply grateful to the village of Kangiqsualujjuaq and the Kangiqsualujjuamiut for their warm welcome. Nakurmiik. This article was written thanks to funding from Fonds Québécois de la Recherche and Fonds Vert of the Government of Québec (Grant No. 2019GS-261860), the Doing Things Differently research project of the Sentinel North program at Université Laval (Canada First Research Excellence Fund), and scholarships from the Social Sciences and Humanities Research Council and the Institut Hydro-Québec en Environnement, Développement et Société.

\section{Conflict of Interests}

The authors declare no conflict of interests.

\section{References}

Agyeman, J. (2005). Sustainable communities and the challenge of environmental justice. New York University Press.

Allard, M., Lemay, M., Barrett, M., Sheldon, T., Brown, R., 
\& Whiteley, S. (2012). Science to policy in Nunavik and Nunatsiavut: Synthesis and recommendation. In M. Allard \& M. Lemay (Eds.), Nunavik and Nunatsiavut: From science to policy. An integrated regional impact study (IRIS) of climate change and modernization (pp. 28-30). ArcticNet.

Archer, D., Almansi, F., DiGregorio, M., Roberts, D., Sharma, D., \& Syam, D. (2014). Moving towards inclusive urban adaptation: Approaches to integrating community-based adaptation to climate change at city and national scale. Climate and Development, 6(4), 345-356.

Barry, J., \& McNeil-Cassidy, J. (2019). Les droits des autochtones et l'urbanisme: De la reconnaissance à une coexistence significative? [Indigenous people's rights and urbanism: From recognition to significant coexistence?]. Plan Canada, 59(1), 52-56.

Blais, M., \& Pinard, E. (Eds.). (in press). Construire et habiter l'Inuit Nunangat/Building and dwelling in Inuit Nunangat. Études Inuit Studies.

Breton, M.-P., \& Cloutier, G. (2017). Cadre institutionnel et pratiques locales de l'aménagement en territoire nordique: Un dialogue en trois temps illustré par le cas de Kuujjuaq [Institutional framework and northern territory local planning practices: A threepart dialogue illustrated by the case of Kuujjuaq]. Recherches Amérindiennes au Québec, 47(1), 87-99.

Campbell, S. (1996). Green cities, growing cities, just cities? Urban planning and the contradictions of sustainable development. Journal of the American Planning Association, 62(3), 296-312.

Chabot, M. (1995). Les "Nunavimiut" et les "Quliriit" à la conquête de l'espace : Participation des citoyens, logements sociaux et aménagement du territoire dans la région Kativik ["Nunavimiut" and "Quiliriit" at the conquest of space: Citizens participation, social housing, and land planning in the Kativik region] [Master thesis, Université Laval]. CorpusUL.

Chu, E., Anguelovski, I., \& Roberts, D. (2017). Climate adaptation as strategic urbanism: Assessing opportunities and uncertainties for equity and inclusive development in cities. Cities, 60, 378-387.

Cloutier, G., Joerin, F., Dubois, C., Labarthe, M., Legay, C., \& Viens, D. (2015). Planning adaptation based on local actors' knowledge and participation: A climate governance experiment. Climate Policy, 15(4), 458-474.

Cuerrier, A., Brunet, N. D., Gérin-Lajoie, J., Downing, A., \& Lévesque, E. (2015). The study of Inuit knowledge of climate change in Nunavik, Quebec: A mixed methods approach. Human Ecology, 43(3), 379-394.

Desbiens, C. (2017). Un nouveau sens du lieu? "L'effet urbain" dans les communautés du Nunavik [A new sens of space? "The urban effect" in Nunavik communities]. Recherches Amérindiennes au Québec, 47(1), 151-154.

Downing, A., \& Cuerrier, A. (2011). A synthesis of the impacts of climate change on the First Nations and
Inuit of Canada. Indian Journal of Traditional Knowledge, 10(1), 57-70.

Duhaime, G. (1985). De l'igloo au H. L. M.-Les Inuit sédentaires de l'État-providence [From igloo to $\mathrm{H}$. L. M.-Sedentary Inuit from the welfare state]. Centre d'Études Nordiques.

Duhaime, G., Caron, A., \& Lévesque, S. (2015). Le Nunavik en chiffres 2015: Version de poche [Nunavik in numbers 2015: Pocket version]. Chaire de recherche du Canada sur la condition autochtone comparée. http://www.chaireconditionautochtone.fss.ulaval. $\mathrm{ca} /$ documents/pdf/Nunavik-en-chiffres-vf-fr.pdf

Durkalec, A., Furgal, C., Skinner, M. W., \& Sheldon, T. (2015). Climate change influences on environment as a determinant of Indigenous health: Relationships to place, sea ice, and health in an Inuit community. Social Science \& Medicine, 136/137, 17-26.

Fainstein, S. S. (2005). Cities and diversity: Should we want it? Can we plan for it? Urban Affairs Review, 41(1), 3-19.

Fédération des Coopératives du Nouveau Québec. (2018). Petrol. http://www.fcnq.ca/en/petrole

Finn, D., \& McCormick, L. (2011). Urban climate change plans: How holistic? Local Environment, 16(4), 397-416.

Ford, J. D., Bolton, K. C., Shirley, J., Pearce, T., Tremblay, M., \& Westlake, M. (2012). Research on the human dimensions of climate change in Nunavut, Nunavik and Nunatsiavut: A literature review and gap analysis. Arctic, 65(3), 289-304.

Ford, J. D., Couture, N., Bell, T., \& Clark, D. G. (2018). Climate change and Canada's north coast: Research trends, progress, and future directions. Environmental Reviews, 26, 82-92.

Ford, J. D., McDowell, G., \& Jones, J. (2014). The state of climate change adaptation in the Arctic. Environmental Research Letters, 9(10), Article 104005.

Henderson, J. S. Y. (2000). Ayukpachi: Empowering aboriginal thought. In M. Battiste (Ed.), Reclaiming indigenous voice and vision (pp. 248-278). University of British Columbia Press.

Hervé, C. (2019). Services publics et autonomie chez les Inuits du Nunavik (Arctique québécois): Perspectives ontologiques sur la gouverne des communs sociaux [Public services and autonomy among Nunavik Inuit (Arctic Quebec): Ontological perspectives on the governance of social commons]. Anthropologies et Sociétés, 43(2), 131-151.

Heyes, S. A. (2011). Cracks in the knowledge: Sea ice terms in Kangiqsualujjuaq, Nunavik. The Canadian Geographer, 55(1), 69-90.

Innes, J., \& Booher, D. (2015). A turning point for planning theory? Overcoming dividing discourses. Planning Theory, 14(2), 195-213.

Kativik Regional Government, \& Makivik Corporation. (2012). Plan Nunavik. Avataq Cultural Institute. https://parnasimautik.com/wp-content/uploads/ 2013/02/Plan_Nunavik_06_20.pdf 
Kendrick, A. (2013). Canadian Inuit sustainable use and management of Arctic species. International Journal of Environmental Studies, 70(3), 414-428.

Klinsky, S., Roberts, T., Huq, S., Okereke, C., Newell, P., Dauvergne, P., O’Brien, K., Schroeder, H., Tschakert, P., Clapp, J., Keck, M., Biermann, F., Liverman, D., Gupta, J., Rahman, A., Messner, D., Pellow, D., \& Bauer, S. (2017). Why equity is fundamental in climate change policy research. Global Environmental Change, 44, 170-173.

Kovach, M. (2009). Indigenous methodologies: Characteristics, conversations and contexts. University of Toronto Press.

Larsen, J. N., Anisimov, O. A., Constable, A., Hollowed, A. B., Maynard, N., Prestrud, P., Prowse, T. D., \& Stone, J. M. R. (2014). Polar Regions. In V. R. Barros, C. B. Field, D. J. Dokken, M. D. Mastrandrea, K. J. Mach, T. E. Bilir, M. Chatterjee, K. L. Ebi, Y. O. Estrada, R. C. Genova, B. Girma, E. S. Kissel, A. N. Levy, S. MacCracken, P. R. Mastrandrea, \& L. L.White (Eds.), Climate change 2014: Impacts, adaptation, and vulnerability. Part B: Regional aspects. Contribution of working group II to the fifth assessment report of the Intergovernmental Panel on Climate Change (pp. 1567-1612). Cambridge University Press.

Makivik Corporation. (n.d.). Nunavik maps. https://www. makivik.org/nunavik-maps

Makivik Corporation. (2019). Tarquti energy corporation. https://www.makivik.org/tarquti-energy-corporation

Makivik Corporation, Kativik Regional Government, Kativik School Board, Nunavik Landholding Corporations Association, Saputiit Youth Association of Nunavik, Nunavik Regional Board of Health and Social Services, \& Avataq Cultural Institute. (2014). Parnasimautik: Consultation report on the consultations carried out with Nunavik Inuit in 2013. https:// parnasimautik.com/2014-consultation-report

Matunga, H. (2013). Theorizing Indigenous planning. In D. C. Natcher, R. C. Walker, \& T. S. Jojola (Eds.), Reclaiming Indigenous planning (pp. 3-32). McGill-Queen's University Press.

McDonald, N. C., \& Pearce, J. M. (2013). Community voices: Perspectives on renewable energy in Nunavut. Arctic, 66(1), 94-104.

Mebratu, D. (1998). Sustainability and sustainable development: Historical and conceptual review. Environmental Impact Assessment Review, 18, 493-520.

Meerow, S., \& Woodruff, S. C. (2020). Seven principles of strong climate change planning. Journal of the American Planning Association, 86(1), 39-46.

Mercer, N., Parker, P., Hudson, A., \& Martin, D. (2020). Off-grid energy sustainability in Nunatukavut, Labrador: Centering Inuit voices on heat insecurity in diesel-production communities. Energy Research \& Social Sciences, 62, Article 101382.

Newell, S. L., Doubleday, N. C., \& Community of Chesterfield Inlet, Nunavut. (2020). Sharing country food: Connecting health, food security and cultural conti- nuity in Chesterfield Inlet, Nunavut. Polar Research, 39, Article 3755.

Odgaard, U. (2003). Hearth and home of the PalaeoEskimos. Études Inuit Studies, 27(1/2), 349-374.

Owusu, P. A., \& Asumadu-Sarkodie, S. (2016). A review of renewable energy sources, sustainability issues and climate change mitigation. Cogent Engineering, 3(1), Article 1167990.

Porter, L., Rickards, L., Verlie, B., Bosomworth, K., Moloney, S., Lay, B., Latham, B., Anguelovski, I., \& Pellow, D. (2020). Climate justice in a climate changed world. Planning Theory \& Practice, 21(2), 293-321.

Rapinski, M., Payette, F., Sonnentag, O., Herrmann, T. M., Royer, M.-J. S., Cuerrier, A., Siegwart Collier, L., Hermanutz, L., \& Guanish, G. (2017). Listening to Inuit and Naskapi peoples in the eastern Canadian Subarctic: A quantitative comparison of local observations with gridded climate data. Regional Environmental Change, 18(1), 189-203.

Rodon, T. (2017). Development in Nunavik: How regional and local initiatives redefine sustainable development in Nunavik. American Review of Canadian Studies, 47(2), 176-188.

Rodon, T., \& Schott, S. (2014). Towards a sustainable future for Nunavik. Polar Record, 50(254), 260-276.

Schrock, G., Bassett, E. M., \& Green, J. (2015). Pursuing equity and justice in a changing climate. Journal of Planning Education and Research, 35(3), 282-295.

Therrien, A., \& Duhaime, G. (2017). Le logement social au Nunavik: Pouvoirs et responsabilités [Social housing in Nunavik: Powers and responsibilities]. Recherches Amérindiennes au Québec, 47(1), 101-110.

Trottier, F., Bayle, M., \& Paquet, A. (2020). Pinasuqatigiitsuta: Community planning in Nunavik. Pinasuqatigiitsuta. https://www.pinasuqatigiitsuta.org

Vachon, G., Boudreault, S., Côté, A., Lambert, É., Proulx, S., \& Dionne, M.-È. (2019). Imagining the North in 50 projects: Creation, collaboration, action. École d'Architecture de l'Université Laval.

Vachon, G., Rivard, E., Avarello, M., \& St-Jean, L. (2017). Imaginer l'aménagement soutenable des villages Innuits du Nunavik: Le design pour réfléchir aux possibles [Imagining sustainable planning for Nunavik villages: A design approach for thinking the possible]. Recherches Amérindiennes au Québec, 47(1), 137-150.

Watt-Cloutier, S. (2019). Le droit au froid: Le combat d'une femme pour protéger sa culture, l'Arctique et la planète [The right to be cold: One woman's story of protecting her culture, the Arctic, and the whole planet]. Éditions Écosociété.

Weis, T. (2014). Implementation of wind energy projects in the autonomous networks and their coupling with diesel powered generators: Barriers, solutions and elements for a roadmap to success. Regroupement des Organismes Environnementaux en Énergie. http://publicsde.regie-energie.qc.ca/projets/232/ 
DocPrj/R-3864-2013-C-ROE\%C3\%89-0044-PreuveRappExp-2014_05_15.pdf

Wilson, S. (2008). Research is ceremony: Indigenous research methods. Fernwood Publishing.
Yin, R. K. (2011). Qualitative research from start to finish. Guilford Press.

Young, I. M. (1990). Justice and the politics of difference. Princeton University Press.

\section{About the Authors}

Antoine Paquet is a graduate student in urban and land planning at Laval University (Québec, Canada). He holds a degree in Environmental Studies (BSc, 2018) from the same institution. His master's thesis focuses on the sociocultural, environmental, and governance-related aspects of the energy transition in Northern Quebec.

Geneviève Cloutier is an associate professor in urban and land planning at Laval University (Québec, Canada). Her research explores public participation, citizen initiatives, urban governance, and climate change planning and action. She is a registered urban planner (Ordre des Urbanistes du Québec).

Myriam Blais is a professor in architecture at Laval University (Québec, Canada), as well as a registered architect (MOAQMember of the Ordre des Architectes du Québec). She holds degrees form Laval University (Bachelor of Architecture, 1983, and Master of Architecture, 1987), and the University of Pennsylvania (PhD, 1994). She teaches studios, architectural theories, research methods, and thesis projects. Her research interests focus on the theories and philosophy of representation. She has been involved in international cooperation projects (Vietnam) and, more recently, with Northern Quebec indigenous communities (Inuit and Innu) on housing challenges and issues. 